\title{
Maybe-ing and must be-ing in higher education
}

\section{Introduction}

In developing a new academic journal, our core intention, as mentioned in previous editorials, has been to generate, disseminate, and promote the interrogation of knowledge and scientific and/or philosophical investigation of higher education. This is our way of promoting the important and critical task of sustaining higher education, and indeed higher education research, as maybe-ing arenas' ${ }^{1}$. By this, we mean sustaining spaces of possibility; of pushing at the boundaries not only of what IS, but also of what is thinkable, knowable, and doable; of imagining how things can be otherwise.

In terms of higher education, the notion of maybe-ing arenas suggests spaces in which everyone involved in higher education (e.g., academics, teachers, students, managers, administration staff) can individually and collaboratively explore possibilities of how they, society, and life can be. Higher education could be a space for creating alternative futures, whether through study; research and discovery; teaching; professional learning; managing; organising; leading; consulting; engaging with various communities of practice, the communities we live in, and with industry; or contributing to journals - especially those, like ours, aimed at maybe-ing! If we accept that higher education plays a role in addressing societal issues (see Giroux, 2010), sustaining maybe-ing spaces seems crucial at this historical moment. We live in a world where more and more nations, groups, and individuals face growing threats from narrow minded -even dangerousconservative interests, conflict, social injustices, and/or threats to our health, professions, and our planet. We also live in a time when the issues we face are becoming increasingly complex (Barnett, 2000). Such issues and complexity arguably demand creative responses and solutions.

Yet, in reality, there are many respects in which higher education is being increasingly colonised by particular forms of normative must be-ing (Mahon, 2014). Keeping spaces 'open' can be a challenge, since there is a clear and constant tension between 'what should be' (must be-ing) and 'what could be' (maybe-ing). Our work, in launching an unconventional journal, within a highly conventional field (higher education), has situated JPHE squarely in the center of this transnational tension. Neoliberal policy and academic capitalism turns are driving an increased must be-ing orientation. 21st century reforms have caused a

\footnotetext{
${ }^{1}$ The idea of a 'maybe-ing arena' versus 'must be-ing arena' in higher education (Mahon, 2014) is based on the concept of a 'maybe-ing arena' used in an unknown source related to outdoor education published prior to 2001. We have tried to find the original source but without success. The Editors would be grateful for any information about the source.
} 
fundamental global transformation in the way institutions of higher education are defined, run, and forced to justify their institutional existence and practices (Beach, 2013). The market-like conditions that this creates force all actors within academia to compete within (quasi-) market conditions, performance-based research funding, and publishing norms that, in many ways, reduce opportunities for innovation in both research and teaching in higher education.

In terms of higher education research, or scientific work in general, researchers are constantly part of debates within and across their respective scientific communities. Some of these debates concern ideas about, or challenge, 'truth(s)'. These debates are not absolute. They are constantly in flux, and we see this dynamic flux as positive. We have seen examples of what happens as a result of false scientific claims ${ }^{2}$ and the consequences such claims can have for the legitimacy of the higher education institution. However, in this debate we also see risks associated with claiming something to be more 'true' than something else. A lot of cultural over-simplification - in science, as in politics - all too easily suffocates alternative claims of thinking otherwise. In our work in JPHE, we find ourselves asking if academic values, norms, and beliefs about publishing academic papers might inadvertently prescribe and limit some types of research(ers), while unfairly rewarding others. The result within this nexus of tensions - whether we get it right or wrong - is our journal.

Both must be-ing and maybe-ing, as we show in this editorial, are needed in higher education and in scientific work. However, the prioritisation of one over the other and denial of the tension between them, can be problematic. Our aim is thus to engage these ideas and consider the tensions between maybe-ing and must being, not only for those involved in higher education and higher education research, but also for JPHE. We discuss these orientations one at a time, exemplifying some of the ways in which they are perceived and experienced across academia. We then explore tensions associated with navigating both, using our experiences of establishing $J P H E$ to illustrate some of our reflections. We conclude by considering the role of courage in ongoing work with these tensions. The discussion is meant to serve as an opening for critical dialogue rather than any kind of answer to the challenges we face.

\section{A maybe-ing orientation?}

In some respects, the expression maybe-ing is relevant to the basic missions (teaching, research, and engagement) of contemporary universities, although such missions manifest differently across institutions, disciplines, and geographical settings. A core purpose of universities, cutting across all three missions, is arguably that of 'knowledge work' (Bullen et al., 2010, p. 54), for instance, knowledge acquisition, the dissemination of knowledge, access to knowledge, and knowledge generation (see Nixon, 2011; Habermas, 1989; Calhoun, 2006). New insights (including reflexive insights) and discoveries can be empowering and/or generative, leading to new understandings, opportunities, and possibilities for action and thought, for example, within disciplines, professions, and communities. This extends to cultural knowledge and connects to the role of universities in terms

\footnotetext{
${ }^{2}$ See for example the so-called 'Paolo Macchiarini affair'.
} 
of cultural transmission and cultural self-understandings (see Habermas, 1989) as well as to the 'continuity and creativity of culture' (Calhoun, 2006, p. 10).

Related to this, universities also serve a civic purpose, which is in line with the notion of higher education as a public good (Nixon, 2011) or as public good (Solbrekke \& Sugrue, 2020). This purpose is fulfilled in part through the formation of citizens (Giroux, 2010; Walker 2002). Universities play an important role, for instance, in enabling people to participate meaningfully, and in an informed way, in public life (Giroux, 2010). Universities also contribute to the formation of societies. This occurs through social critique (Bleiklie, 1998); helping to address social issues (Giroux, 2011); and by informing and framing public debate (see Habermas 1989; Giroux, 2010). Crucial debates from a maybe-ing perspective would concern what constitutes a public good (see Nixon, 2011), as well as, what different possibilities, positions, and goals can be collectively enabled.

Another important purpose of universities is the formation of professionals (see Bleiklie, 1998; Calhoun, 2006) and, through professional education and research, the formation (and transformation) of the professions (e.g., Lee \& Dunston, 2011). Many people engage in higher education in the hope of opening doors to a (new) career. In doing this, they in some ways embrace the possibility of being and becoming some other form or version of themselves (professionally speaking) and/or of being part of a (new) profession. If they graduate, and become part of their chosen profession, they can also possibly contribute to the development of that profession. Maybe-ing might be more relevant to some professions than others, however. For instance, in many established professions, like accounting, professional pilot, or in certain parts of the military, there can be less scope or need in particular aspects of the work involved for creativity, and more demand for predictability, order, and precision.

Universities also serve an economic purpose (Bleiklie, 1998) by providing particular services and generating products (e.g., new technologies, innovations) that are of local and national economic benefit (Calhoun, 2006). They also produce an educated workforce. Although there is an extent to which an economic focus is increasingly dominating the work of universities at the expense of other functions (Bleiklie, 1998), it is also apparent that university-based enterprise can take humanity into previously inconceivable realms.

All of these purposes connect in some way to the ideal of higher education as a site for human flourishing (Nixon, 2011). For instance, higher education, despite the existing impediments and ongoing struggles for equity, has provided women with opportunities to change the directions of their lives from gender stereotyped paths. They can pursue their own dreams in the intersections of student and/or faculty member with the must be subject positions of a 'daughter', 'wife', and 'mother'. In this sense, higher education has helped create the possibility of may be subject positions and functioned as a site of human flourishing for women (Khalifeh Soltani, 2020).

The construct of maybe-ing is particularly relevant to higher education research. Higher education research, like any research, could be considered maybeing to the extent that it is curiosity-driven and/or involves venturing into the unknown. Some might also say that higher education research can be maybe-ing if it embraces plurality, opening up possibilities by allowing for multiple interpretations, multiple knowledges and ways of knowing, and multiple realities. Praxis-oriented critical research, we suggest, is a kind of research that especially reflects a maybe-ing orientation. Such research seeks to generate knowledge that 
may lead to a better world/reality/situation/practice while changing - and being changed by it. Put another way, an orientation to praxis aims for an understanding of the world (who are we? what are we doing? why?) and a remaking of it at the same time. This is the kind of ongoing, transnational journey and dialogue our journal hopes to actively facilitate and directly support.

\section{A must be-ing orientation?}

Just as we have maybe-ing aspirations, conditions, and practices shaping how higher education and research unfold, we also have must be-ing aspirations, conditions, and practices, which constrain what we do and how. Policies, schedules, formulas, and prescribed procedures and other such constraining phenomena are must be-ing aspects of everyday life, work, and study, shaping and informing activity and thinking in varying ways. In some contexts and respects, this is unavoidable, warranted, or even desirable. Must be-ing practices can be, for instance, relevant to the preservation of human life or dignity; the stabilisation and security of communities and organisations; or the prevention of environmental devastation and oppression and exploitation of people. However, there is a sense in which both higher education and scientific work are becoming increasingly oriented by top-down, instrumental and pragmatic, economically driven must be-ing (rather than ground-up, curiosity-driven maybe-ing). And this imbalance, we suggest, is cause for concern.

In higher education, academics, students, and other members of university communities are constantly exposed (and perhaps contribute) to norms and expectations that shut down possibilities of action and thought instead of opening them up (Davids \& van Eerdewijk, 2016). These norms and expectations are increasingly made explicit and institutionalised, it would seem, through written texts (e.g., policy documents; quality assurance checklists; accreditation or audit criteria; standardised forms and templates, assessment exemplars; schedules), some of which are top-down directives. They are also sometimes so implicitly embedded and perpetuated and/or 'naturalised' in our practices and discourses that we take them for granted and no longer recognise or even see their constraining, must being effects (Watermeyer \& Olssen, 2016). This can be so despite the widespread cautionary tales in higher education scholarship about the rise of performativity (Ball, 2012), managerialism (Morley \& Crossouard, 2016), and an audit culture (Shore \& Wright, 2004).

How time is treated in higher education is one example of what we have been alluding to. It seems that a steadily increasing number of people working and studying in higher education are being ruled by, and obeying, time sheets and schedules (Widmalm, Bennich-Björkman, Jarstad, Ahlbäck Öberg, Hermansson, \& Karlsson, 2016). What is accomplished by continuously measuring the time it takes to reach a goal or fulfil a task? An Ethiopian doctoral researcher recently asked one of us how we, in Swedish Higher Education, know when to stop thinking. The question came after a doctoral seminar which, in Sweden, tends to be strictly time controlled, with no allowance for delays. For him, the time-slot of an hour and a half for a seminar was far too short, and he wondered why the conversation had to stop, just when things had finally started to become interesting. The answer to this is, at least partly, that time has become for many higher education institutions 
around the world part of how we regulate and measure what we produce and when (Widmalm, et al., 2016). The clock is ticking.

This is part of a broader preoccupation with efficiency that many associate with, among other things ${ }^{3}$, the neoliberalisation of society (Peck \& Tickle, 2002), a process by which a market logic has affected and transformed many social, political, and economic aspects of life across the globe. Higher education, within this context has had to adapt to market needs, and in some cases, works against the notion of education as a public good (Olssen, 2016). An increased control of higher education by the market has meant that economic discourses are increasingly foregrounded at the expense of an independent maybe-ing space (Olssen, 2016).

Paradoxically, must be-ings frequently occur in higher education even when the opposite effect is explicitly stated as a goal. Internationalisation is a good case in point. Internationalisation is often framed as self-evident, objective, and valueneutral (Angervall \& Simonsson, in press), and there are claims that it both enhances and is a facet of widening participation. However, more critical analyses highlight, ironically, that internationalisation often benefits or includes only some populations served by higher education, not all populations (see also Stromquist, 2007). The idea that there is a standard, or 'one-size-fits-all' or valuefree, approach to internationalisation will not stand up to a critical analysis of the intersection between $21^{\text {st }}$ century migration, mobilities, and internationalisation. Uncritical approaches to internationalisation is an example of how must beings obscure blind spots, across global and Nordic higher education (Hoffman, Khan, Habti, Ndomo, \& Lima-Toivanen, 2020).

A similar paradox can be found in higher education research and scientific work more generally. Conclusions are sometimes drawn in scientific and philosophical debates (based on a critique of scientific relativism) that research should be about stating facts and finding neutral and objective answers, while critical and more relativist research standpoints are discussed as dangerous, or based on confusion or left-wing ideologies ${ }^{4}$. The idea of (some) research is to generate new insights, but this possibility is potentially diminished if aspects of the inquiry are too fixed or normative to begin with, or if those conducting the inquiry have more or less already arrived at the answers. (See Melina Aarnikoivu, this issue, for a discussion of nexus analysis within doctoral education research that challenges precisely this tendency). This contrasts with a maybe-ing notion in research of keeping alive the search for new knowledge. If higher education and research about higher education drift too far into being 'fixed' at the must be-ing end of the spectrum, we cede the creative tension of maybe-ing - at the opposite end of that spectrum (see Hoffman, Nokkala, \& Välimaa, 2016). This is particularly relevant to diversity work ${ }^{5}$. Sometimes leaders/managers work to accomplish a more gender equal higher education sector, for example, yet normative concepts and methods are used to study gender related issues. (See Leathwood \& Read, 2009, and Angervall \& Beach, 2018, who have tracked and debated the hegemonic relationships established in and between different academic and scientific settings). We need to ask whose gender equality is fixed by this (Davids \& van Eederwijk, 2016)?

\footnotetext{
${ }^{3}$ For example managerialism, or a means-ends, technical rationality.

${ }^{4}$ See Hämäläinen (2019).

${ }^{5}$ See the discussion by Davids \& van Eederwijk (2016) of the risks involved in prescribing particular facts and solutions in the context of gender mainstreaming.
} 
Scientific communities are must be-ing in other ways as well. It is now widely recognised (see Widmalm, et al., 2016) that researchers are obliged to play certain rules of the 'academic' game in order to survive and thrive in academia, and the domain of higher education research is no exception. There are spoken and written, as well as unspoken and unwritten, rules (reinforced by economic incentives and penalties) about how much one ought to publish per year, where to publish, and with whom to publish. Publishing in international peer-reviewed articles in high stake journals has become more 'acceptable' or 'valuable' in many contexts than publishing in book chapters or in national and professional practice forums, for example. Although it seems to change with national political agendas (especially when connected to state funding), what to research and publish about also seems to be somewhat prescribed. We return to this point later in relation to the journal.

In many respects, we can talk about elements of academic culture and academic life that constrain our practices and praxis as walls. Walls are, in Ahmed's view (2016), 'those hardenings of history into barriers in the present' (p. 135). The question of how to deal with the walls within and shaping academia, and how to keep academic spaces open is part of an ongoing source of tension for many. We explore this tension in more detail next.

\section{Maybe-ing-must be-ing tensions}

Maybe-ing and must be-ing are clearly at odds with each other, even though both have a place in contemporary higher education and science. Indeed, both are in high demand in some ways. The mustbe-ing areas of higher education and higher education research can help 'pay the bills' and deliver crucial outcomes and deliverables for a wide range of stakeholders who need predictability and stability (reproduction, stability, and continuity). The most creative areas of higher education and higher education research define the cutting edge of knowledge (transformation, change, and discontinuity).

There are at least four additional tensions that add complexity to this already complex tension. First, as suggested above, not all maybe-ings are generative, or perhaps what might appear to be maybe-ings for some amount to a shutting down of possibilities for others. This heightens the need for critical debate about our frames of reference and what maybes and must bes we need and can live with. Second, when we try (that is if we try) to transform our conditions, we as academics, students, leaders, researchers, policy makers, journal editors are actually part of the conditions we are trying to change. This means that our sense making is mediated by those same conditions, which may create walls in ways that we are not even fully aware of until it is too late. For instance, a must be-ing logic can dull the imagination in ways that perpetuate itself. This includes the 'methodological imagination' (Fine, 2018) and the 'sociological imagination' (Mills, 1959). Third, higher education can be a maybe-ing arena for those within it in, and the same applies to higher education research, but both are exclusive spaces in a sense. Fourth, we cannot not act, and our actions once performed cannot be undone. This means that at some point in our daily activity we have to make decisions and take action, and this in turn means a kind of closing down of options as we go about our work (and lives). So there is an inevitable limit to maybe-ing as we have described it.

We have experienced these tensions first hand in establishing this journal. Our aspiration for JPHE from the outset has been to ultimately make a difference 
to the higher education landscape, at both local and global levels, partly by being a bit different from the higher education journals already in existence (see our inaugural editorial for a more detailed account of our aspirations. $)^{6}$ In order to live up to such aspirations, a journal must first of all survive, which goes hand in hand with earning the respect and interest of the academic community. For that, certain standards must be set, reached, and then maintained, and the journal needs to be noticed. All of these things require (a) resources, and (b) living up to certain expectations of what an academic journal is, so that potential readers and contributors will recognise it as one.

The resources needed to establish and manage a journal cannot be underestimated due to the administrative and scholarly work involved. JPHE is a not-for-profit journal because of a commitment to open access publishing to and broadening research-based debate about higher education. This makes JPHE, as a new journal, somewhat vulnerable with respect to resources. It relies heavily on 'volunteers', good will within the academic community (for example its Editorial Board members), and institutional support (i.e., from our own institutions). External funding can obviously make a significant difference. However, in order to be granted funds, a journal needs a 'track record', and this is difficult to establish without adequate funds to begin with. So what JPHE may be as a journal is constrained by scientific funding conditions, and also its own ambitions, which make certain funding conditions relevant.

Expectations of potential contributors are also relevant here because a 'track record' is not possible without submissions. A journal does not actually exist without submissions. We have been fortunate to receive exciting and interesting contributions to the journal so far, but to sustain the debate, and have ongoing regular issues, JPHE, like other journals, is compelled to meet certain criteria for authors to consider the journal worthy of their work. This includes impressions of quality, focus, and readership, and, increasingly in this neoliberal age, factors related to rankings, impact, doi numbers, and cross referencing systems. Many institutions now require their academic staff to publish in high stake journals. Indeed promotions, salary, and future funding can depend on it (see e.g., Hammarfelt, de Rijcke \& Wouters, 2017). A so called 'Norwegian list' is used in the Swedish higher education sector to identify how much value a single publication has on the open academic market. The list and others like it appear to be prescribing how journals are to be measured/judged and selected, and how journals and publications ought to take shape and locate themselves.

This begs the question of how a journal like JPHE can maintain itself as a maybe-ing space and avoid contributing to the sea of demands and must bes being placed on the academic community. How can this journal, or indeed anyone associated with higher education and research, achieve ambitions to challenge aspects of 'the game' (or even 'the game' itself) while in some respects being part of the game? We think this is a tightrope - stretched between maybe-ing and mustbe-ing. The object of the game, for us, will be a continuous balancing act, as our journal moves forward.

\footnotetext{
${ }^{6}$ Editorial, Vol.1, No. 1 (Aarnikoivu, Mahon, Agnafors, Hoffman, \& Angervall, 2019).
} 


\section{Conclusion: Imagine the academy as something different}

In this Editorial, we have painted a picture of higher education and higher education research as sites of a must be-ing-maybe-ing tension. We have also highlighted some of the ways in which this journal aspires to continue to respond to this tension, and the must be-ing walls created by, for example, standards, ready-made methods, norms, and expectations, and pressure to produce and settle on answers. We are not alone in this. Many academics and others in the higher education community work daily to keep spaces 'open' and push back against an ever-spreading must be-ing logic. Such work can be risky and demand inventiveness, as Ahmed's (2016) words suggest:

When we come up against walls, how easily things shatter. To be shattered can be to experience the costs of our own fragility: to break, to reach a breaking point. How can we aim for breakages, and how can we become inventive in dealing with them? (p. 163)

Push back (or 'breakages') means daring to be vulnerable, and so it requires courage, from our perspective at least; courage to stay critical. What can give us courage and energy in the face of walls is our solidarities with others, the kinds of solidarities derived from working with others in a common project and in meaningful conversations.

JPHE is a journal dedicated to such conversations, to furthering understandings of how things are in higher education and higher education research (and what we are doing, and the (potential) consequences of what we are doing), which is an important part of helping us to stay critical. Articles in this JPHE issue by Serafina Pastore about student conceptions of assessment, and Jan Gustafsson Nyckel, Rolf Lander, and Per-Olof Thång on reflective practice in a preschool teacher education program are examples of this. JPHE is also dedicated to understanding how things may be if we dare to consider and pursue creativity in our everyday work (for an example, see the article by Anne Algers and Linda Bradley in this issue which offers novel ways to think about and engage programs, like teacher education programs, that comprise our everyday work). In this sense, we have an ambition to help shift the prevailing conversations in academia towards what is possible and towards making change possible, especially in areas where urgent change is needed. We hope the collection of contributions will promote, over time and in a substantial way, the courage, criticality, and collective efforts needed to achieve what may be.

Kathleen Mahon, Petra Angervall, Sara Khalifeh Soltani, David Hoffman, Melina Aarnikoivu, Lill Langelotz, and Catarina Player Koro 


\section{References}

Aarnikoivu, M., Mahon, K., Agnafors, M., Hoffman, D., \& Angervall, P. (2019). Another higher education journal - Really? Journal of Praxis in Higher Education, 1(1), 1-9. http://jphe.org/current-issue/

Ahmed, S. (2016). Living a feminist life. Durham: Duke University Press.

Angervall, P., \& Beach, D. (2018). The exploitation of academic work: Women in teaching at Swedish universities. Higher Education Policy, 31(1), 1-17, doi:10.1057/s41307-017-0041-0

Angervall, P., Beach, D., \& Gustafsson, J. (2015). The unacknowledged value of female academic labour power for male research careers, Journal of Higher Education Research \& Development, 13(5), 815-827. doi:10.1080/07294360.2015.1011092

Angervall, P., \& Simonsson, A. (in press). (Im)mobility and (e)quality in Swedish higher education. In R. Watermeyer, R., Olssen, M., \& Raaper, R. (Eds.), Handbook of academic freedom. Cheltenham: Edward Elgar

Ball, S. J. (2012). Performativity, commodification and commitment: An I-spy guide to the neoliberal university. British Journal of Educational Studies, 60(1), 17-28. doi:10.1080/00071005.2011.650940

Barnett, R. (2000). University knowledge in an age of supercomplexity. Higher Education, 40(4), 409-422. doi:10.1023/a:1004159513741

Beach, D. (2013). Changing higher education: Converging policy-packages and experiences of changing academic work in Sweden. Journal of Education Policy, 28(4), 517-533. https://doi.org/10.1080/02680939.2013.782426

Bleiklie, I. (1998). Justifying the evaluative state: New pubic management ideals in higher education. European Journal of Education, 33(2), 299-316.

Bullen, E., Kenway, J., \& Fahey, J. (2010). The knowledge economy and research governance: How we got to where we are. In J. Blackmore, M. Brennan \& L. Zipin (Eds.), Re-positioning university governance and academic work (pp. 53-66). Rotterdam, Netherlands: Sense.

Calhoun, C. (2006). The university and the public good. Thesis Eleven, 84(1), 743.

Davids, T. \& van Eerdewijk, A. (2016). The smothering of feminist knowledge: Gender mainstreaming articulated through neoliberal governmentalities in the politics of feminist knowledge transfer. In Bustelo, M., Ferguson, L., \& Forest, M. (Eds.), Gender training and gender expertise (pp. 80-96). Palgrave Macmillan.

Dyrdal Solbrekke, T., \& Sugrue, C. (Eds.). (2020). Leading higher Education as and for public good: Rekindling education as praxis. London: Routledge.

Giroux, H. A. (2010). Bare pedagogy and the scourge of neoliberalism: Rethinking higher education as a democratic public sphere. Educational Forum, 74(3), 184-196.

Habermas, J. (1989). The new conservatism: Cultural criticism and the historians' debate. Cambridge, MA: MIT Press.

Hammarfelt, B., de Rijcke, S. \& Wouters, P. (2017). From eminent men to excellent universities: University rankings as calculative devices. Minerva, 55, 391411. https://doi.org/10.1007/s11024-017-9329-X

Hoffman, D., Jawaria Khan, J., Habti, D., Ndomo, Q., \& Lima-Toivanen, M. (2020). Two decades of internationalization and higher education in Finland: 20 years of experience: Or 1 year - repeated 20 times? In T. 
Saarinen, J. Kallunki, \& T. Seikkinen (Eds.), Consortium of Higher Education Researchers in Finland 20th anniversary festschrift. Jyväskylä: Finland.

Hoffman, D., Nokkala, T. \& Välimaa, J. (2016). 'World class local heroes': Emerging competitive horizons and transnational academic capitalism in Finnish higher education - 2010-2012. In D. Hoffman \& J. Välimaa (Eds.), Re-becoming universities? Higher education institutions in networked knowledge societies (pp. 247-282). Dordrecht: Springer.

Hämäläinen, N. (2019). Är Trump postmodern? En essä om sanning och populism. (Is Trump post-modern? An essay on truths and popularism). Helsinki: NordPrint

Khalifeh Soltani, S. (2020). Jensiat dar tajrobeh zisteye zanandanshjooye doctora dar movajehe ba barnameye darsi dar amuzesh ali dardaneshgah Shahid Beheshti. (Women doctoral students' lived experiences of gender in curriculum in higher education at the University of Shahid Beheshti). Doctoral Dissertation. Faculty of Education and Psychology, Iran: Shahid Beheshti University

Leathwood, C., \& Read, B. (2013). Gender and the changing face of higher education: A feminized future? London: McGraw-Hill Education.

Lee, A., \& Dunston, R. (2011). Practice, learning and change: Towards a retheorisation of professional education. Teaching in Higher Education, 16(5), 483-494. doi:10.1080/13562517.2011.580840

Mahon, K. (2014). Critical pedagogical praxis in higher education. $\mathrm{PhD}$ diss., Charles Sturt University, Wagga Wagga, Australia.

Mills, C. W. (1959). The sociological imagination. Oxford: Oxford University Press.

Morley, L., \& Crossouard, B. (2016) Gender in the neoliberalised global academy: The affective economy of women and leadership in South Asia. British Journal of Sociology of Education, 37(1), 149-168.

Nixon, J. (2011). Higher education and the public good: Imagining the university. London: Continuum.

Olssen, M. (2016). Neoliberal competition in higher education today: Research, accountability and impact. British Journal of Sociology of Education, 37(1), 129-148. doi:10.1080/01425692.2015.1100530

Peck, J., \& Tickell, A. (2002). Neoliberalising space. Antipode, 34(3), 380-404. doi.org/10.1111/1467-8330.00247

Shore, C., \& Wright, S. (2004). Whose accountability? Governmentality and the auditing of universities. Parallax, 10(2), 100-116. doi:10.1080/1353464042000208558

Stromquist, N. P. (2007). Internationalisation as a response to globalization: Radical shifts in university environments. Higher Education, 53, 81-105.

Walker, M. (2002). Pedagogy and the politics and purposes of higher education. Arts and Humanities in Higher Education, 1(1), 43-58.

Watermeyer, R., \& Olssen, M. (2016). 'Excellence' and exclusion: The individual costs of institutional competitiveness. Minerva, 54, 201-218.

Widmalm, S., Bennich-Björkman, L., Jarstad, A., Ahlbäck Öberg, S., Hermansson, J., \& Karlsson, C. (Eds.). (2016). Det hotade universitetet. (The theatened university). Stockholm: Dialogos Förlag. 